\begin{tabular}{|c|c|}
\hline Title & Catalytic oxidation of ammonium ion in water with ozone over metal oxide catalysts \\
\hline Author(s) & Ichikawa, Sho-ichi; Mahardiani, Lina; Kamiya, Y uichi \\
\hline Citation & $\begin{array}{l}\text { Catalysis Today, 232, 192-197 } \\
\text { https://doi.org/10.1016/.caltod.2013.09.039 }\end{array}$ \\
\hline Issue Date & 2014-09-01 \\
\hline Doc URL & http:/hdl.handle.net/2115/56526 \\
\hline Rights & (02013 Elsevier B.V . All rights reserved. \\
\hline Type & article (author version) \\
\hline File Information & CA TTOD-D-13-00351_body text.pdf \\
\hline
\end{tabular}

Instructions for use 


\section{Catalytic oxidation of ammonium ion in water with ozone over metal oxide catalysts}

Sho-ichi Ichikawa ${ }^{1}$ Lina Mahardiani $^{1}$, Yuichi Kamiya ${ }^{2}$

${ }^{1}$ Graduate School of Environmental Science, Hokkaido University, Nishi 5, Kita 10, Kita-ku,

Sapporo 060-0810, Japan

${ }^{2}$ Research Faculty of Environmental Earth Science, Hokkaido University, Nishi 5, Kita 10, Kita-ku,

Sapporo 060-0810, Japan

*Corresponding author

Yuichi Kamiya

E-mail: kamiya@ees.hokudai.ac.jp, Tel/Fax: +81-11-706-2217 
Abstract

Oxidative decomposition of $\mathrm{NH}_{4}^{+}\left(10 \mathrm{mmol} \mathrm{L}^{-1}\right)$ with $\mathrm{O}_{3}$ in water was studied at $333 \mathrm{~K}$ over a variety of metal oxide catalysts without $\mathrm{pH}$ control of the solution. Although $\mathrm{MgO}$ and $\mathrm{NiO}$ had the highest catalytic activities, large amounts of undesired $\mathrm{NO}_{3}{ }^{-}$formed due to low selectivity to gaseous products as well as high activity. $\mathrm{Co}_{3} \mathrm{O}_{4}$, which was slightly less active than $\mathrm{MgO}$ and $\mathrm{NiO}$, was the best catalyst in terms of activity, selectivity to gaseous products, and dissolution degree among the metal oxide catalysts studied. Over $\mathrm{Co}_{3} \mathrm{O}_{4}, \mathrm{NH}_{4}{ }^{+}$was selectively oxidized to $\mathrm{N}_{2}$ with $88 \%$ selectivity in water, and the dissolution degree of $\mathrm{Co}_{3} \mathrm{O}_{4}$ was less than $1 \%$. $\mathrm{Fe}_{2} \mathrm{O}_{3}, \mathrm{SnO}_{2}$, $\mathrm{Mn}_{3} \mathrm{O}_{4}, \mathrm{CuO}, \mathrm{MgO}$, and $\mathrm{Al}_{2} \mathrm{O}_{3}$ were less selective to gaseous products or much less active for the reaction. The selectivities to gaseous products were strongly related to the standard enthalpy changes of formation per mol of oxygen atom $\left(\Delta H_{\mathrm{f}}^{\circ}\right)$ of the metal oxides. The metal oxide catalysts with low $\Delta \mathrm{H}_{\mathrm{f}}^{\circ}$, like $\mathrm{Co}_{3} \mathrm{O}_{4}$, showed high selectivity to gaseous products probably due to the low surface density of the active oxygen formed from $\mathrm{O}_{3}$ on the catalysts. Chloride ions $\left(\mathrm{Cl}^{-}\right)$ present in the reaction solution significantly accelerated the reaction rate for $\mathrm{NH}_{4}{ }^{+}$decomposition with $\mathrm{O}_{3}$ in the presence of $\mathrm{Co}_{3} \mathrm{O}_{4}$. This was due to the involvement of $\mathrm{Cl}^{-}$in the catalytic cycle. For instance, $\mathrm{ClO}^{-}$, which may form by the reaction of $\mathrm{Cl}^{-}$with $\mathrm{O}_{3}$ over $\mathrm{Co}_{3} \mathrm{O}_{4}$, could further oxidize $\mathrm{NH}_{4}{ }^{+}$. 
Keywords: Catalytic ozonation; Ammonia; Metal oxide catalysts; Wastewater treatment; Cobalt oxide 


\section{Introduction}

High concentrations of ammonia $\left(\mathrm{NH}_{3}\right)$ and ammonium ion $\left(\mathrm{NH}_{4}{ }^{+}\right)$, which are collectively called ammonia nitrogen, in domestic, agricultural, and industrial wastewaters cause eutrophication of rivers, lakes, and epeiric seas. In addition, ammonia nitrogen in environmental water causes acute toxicity in fish species even if the concentration is less than $10 \mathrm{mg} \mathrm{L}^{-1}$. Therefore, ammonia nitrogen needs to be removed from wastewater and preferably decomposed into harmless compounds. Current purification technology for wastewater containing ammonia nitrogen is aerobic biological treatment. However, this treatment method is not applicable to wastewater containing toxic compounds, like heavy metals, and $\mathrm{NO}_{3}{ }^{-}$that forms must be reduced to $\mathrm{N}_{2}$ by anaerobic biodegradation. In addition, this treatment method has some disadvantages, such as the need for tight control of the $\mathrm{pH}$, nutritional sources, and temperature of the wastewater and the need for long reaction times and large areas for installing water-purifier tanks.

A promising method complementing the biological treatment method is catalytic wet oxidation (CWO) of ammonia nitrogen in water with $\mathrm{O}_{2}$ [1-11]. In 1985, Imamura et al. [1] first reported CWO of $\mathrm{NH}_{3}$ in water over Ce-based mixed oxides. $\mathrm{NH}_{3}$ oxidatively decomposes at $536 \mathrm{~K}$ and 4.0 $\mathrm{MPa}$ of $\mathrm{O}_{2}$ under strong-alkaline conditions $(\mathrm{pH}=12)$ in the presence of an $\mathrm{MnCeOx}$ catalyst. However, about $50 \mathrm{mg} \mathrm{L}^{-1}$ of undesired, harmful $\mathrm{NO}_{3}{ }^{-}$forms, and the reaction does not proceed at 
all under neutral or acidic conditions. To conduct $\mathrm{CWO}$ of $\mathrm{NH}_{3}$ under relatively mild reaction conditions, van Santen and co-workers have used supported Pt-group metal catalysts, and they have reported that the reaction proceeds below $473 \mathrm{~K}$ over Pt/graphite [3]. Its activity is one order of magnitude higher than the $\mathrm{MnCeOx}$ catalyst [1], and $\mathrm{N}_{2}$ selectively forms at high temperature (453 K). However, undesired by-products, including $\mathrm{N}_{2} \mathrm{O}$ and $\mathrm{NO}_{2}^{-}$, form, and the catalyst is completely deactivated at relatively low temperature $(<433 \mathrm{~K})$ [3]. Taguchi and Okuhara $[4,5]$ have systematically investigated the reactions over supported noble metal (Pt and $\mathrm{Pd}$ ) catalysts at relatively low temperature $(433 \mathrm{~K})$, low pressure $(0.5 \mathrm{MPa})$, and under mild acidic conditions $(\mathrm{pH}=$ 5.5). They report that $\mathrm{Pt} / \mathrm{TiO}_{2}$ decomposes $\mathrm{NH}_{3}$ into $\mathrm{N}_{2}$ with $100 \%$ selectivity [4].

As mentioned above, $\mathrm{CWO}$ of $\mathrm{NH}_{3}$ is quite attractive because $\mathrm{NH}_{3}$ is selectively oxidized to $\mathrm{N}_{2}$. However, previous reports show that $\mathrm{CWO}$ needs reaction temperatures $\geq 423 \mathrm{~K}$, even when noble metal catalysts are used. If the oxidative decomposition of ammonia nitrogen in water could be made to proceed below $373 \mathrm{~K}$, purification of the polluted wastewater could be conducted without a pressure-resistant reactor, which is beneficial from a practical point of view.

Recently catalytic oxidation with $\mathrm{O}_{3}$, which is called catalytic ozonation, has attracted much attention as a method for purifying wastewater to decompose organic compounds in water as well as in gas-phase because the oxidation reaction proceeds near room temperature [12-22]. In fact, 
various metal oxides and supported precious metal catalysts have been examined for use in catalytic ozonation of organic compounds in water $[12,13]$. However, to the best of our knowledge, there is no report on the heterogeneous catalytic ozonation of ammonia nitrogen in water, although non-catalytic ozonation of $\mathrm{NH}_{3}$ [23] and that with a homogeneous catalyst in water [24] have been investigated.

In the present study, to elucidate the catalytic features of metal oxide catalysts, oxidative decomposition of ammonia nitrogen with $\mathrm{O}_{3}$ (eq. 1) in water was performed using various metal oxide catalysts. Since the reaction was conducted under mild acidic conditions and $K_{\mathrm{b}}$ of $\mathrm{NH}_{3}$ $\left(=\left[\mathrm{NH}_{4}^{+}\right]\left[\mathrm{OH}^{-}\right] /\left[\mathrm{NH}_{3}\right]\right)$ is $10^{-4.8}$, almost all of the ammonia nitrogen was present as cationic $\mathrm{NH}_{4}^{+}$, not as $\mathrm{NH}_{3}$, in the reaction solution under the present reaction conditions. In the catalytic ozonation of $\mathrm{NH}_{4}{ }^{+}$, it is necessary to prevent both $\mathrm{NO}_{3}{ }^{-}$(eq. 2) and $\mathrm{NO}_{2}^{-}$(eq. 3) forming because they are much more harmful than ammonia nitrogen. Thus, we carefully examined the formation of these compounds. The reaction mechanism and influence of $\mathrm{Cl}^{-}$in the reaction solution on the catalytic ozonation over $\mathrm{Co}_{3} \mathrm{O}_{4}$ are discussed.

$$
\begin{aligned}
& \mathrm{NH}_{4}^{+}+3 / 2 \mathrm{O}_{3} \rightarrow 1 / 2 \mathrm{~N}_{2}+3 / 2 \mathrm{H}_{2} \mathrm{O}+3 / 2 \mathrm{O}_{2}+\mathrm{H}^{+} \\
& \mathrm{NH}_{4}^{+}+4 \mathrm{O}_{3} \rightarrow \mathrm{NO}_{3}^{-}+\mathrm{H}_{2} \mathrm{O}+4 \mathrm{O}_{2}+2 \mathrm{H}^{+}
\end{aligned}
$$




$$
\mathrm{NH}_{4}{ }^{+}+3 \mathrm{O}_{3} \rightarrow \mathrm{NO}_{2}^{-}+\mathrm{H}_{2} \mathrm{O}+3 \mathrm{O}_{2}+2 \mathrm{H}^{+}
$$

\section{Experiment}

\subsection{Catalyst preparation}

$\mathrm{Co}\left(\mathrm{NO}_{3}\right)_{2} \cdot 6 \mathrm{H}_{2} \mathrm{O}, \quad \mathrm{Ni}\left(\mathrm{NO}_{3}\right)_{2} \cdot 6 \mathrm{H}_{2} \mathrm{O}, \quad \mathrm{Zn}\left(\mathrm{NO}_{3}\right)_{2} \cdot 6 \mathrm{H}_{2} \mathrm{O}, \quad \mathrm{Fe}\left(\mathrm{NO}_{3}\right)_{2} \cdot 6 \mathrm{H}_{2} \mathrm{O}, \quad \mathrm{SnCl}_{4} \cdot 5 \mathrm{H}_{2} \mathrm{O}$,

$\mathrm{Mn}\left(\mathrm{CH}_{3} \mathrm{COO}\right)_{2} \cdot 4 \mathrm{H}_{2} \mathrm{O}, \mathrm{Cu}\left(\mathrm{NO}_{3}\right)_{2} \cdot 6 \mathrm{H}_{2} \mathrm{O}$, aqueous ammonia, and sodium hydroxide were purchased

from Wako Pure Chem. Ind. Ltd. and used without further treatment.

Cobalt oxide $\left(\mathrm{Co}_{3} \mathrm{O}_{4}\right)$ was prepared by a conventional precipitation method. An aqueous ammonia solution $\left(1.0 \mathrm{~mol} \mathrm{~L}^{-1}\right)$ was added to a solution of $\mathrm{Co}\left(\mathrm{NO}_{3}\right)_{2}\left(1.0 \mathrm{~mol} \mathrm{~L}^{-1}\right)$ until the $\mathrm{pH}$ was 8. The suspension was allowed to stand for $10 \mathrm{~min}$ at room temperature. The precipitate that formed was separated by filtration, washed with distilled water, and dried at $373 \mathrm{~K}$ for two days. The solid was then calcined in air at $773 \mathrm{~K}$ for $4 \mathrm{~h}$.

Nickel oxide $(\mathrm{NiO})$ was prepared in a similar manner to that for cobalt oxide calcined at 773 $\mathrm{K}$ using a solution of $\mathrm{Ni}\left(\mathrm{NO}_{3}\right)_{2}$ instead of $\mathrm{Co}\left(\mathrm{NO}_{3}\right)_{2}$. Zinc oxide $(\mathrm{ZnO})$ and iron oxide $\left(\mathrm{Fe}_{2} \mathrm{O}_{3}\right)$ were prepared in a similar manner to that for cobalt oxide, except that the $\mathrm{pH}$ of the solution was 7 , and solutions of $\mathrm{Zn}\left(\mathrm{NO}_{3}\right)_{2}$ and $\mathrm{Fe}\left(\mathrm{NO}_{3}\right)_{2}$, respectively, were used.

Tin oxide $\left(\mathrm{SnO}_{2}\right)$ was prepared as follows. An aqueous ammonia solution $\left(0.5 \mathrm{~mol} \mathrm{~L}^{-1}\right)$ was 
added dropwise to an aqueous solution of $\mathrm{SnCl}_{4}\left(1.0 \mathrm{~mol} \mathrm{~L}^{-1}\right)$ until the $\mathrm{pH}$ of the solution was 8 . The suspension was stirred at $353 \mathrm{~K}$ for $3 \mathrm{~h}$. The precipitate that formed was separated by using centrifugation and dried in air at $383 \mathrm{~K}$ for $24 \mathrm{~h}$, followed by calcination in air at $673 \mathrm{~K}$ for $2 \mathrm{~h}$. Manganese oxide $\left(\mathrm{Mn}_{3} \mathrm{O}_{4}\right)$ was prepared by using a precipitation method. An aqueous solution of sodium hydroxide $\left(0.5 \mathrm{~mol} \mathrm{~L}^{-1}\right)$ was added to an aqueous solution of $\mathrm{Mn}\left(\mathrm{CH}_{3} \mathrm{COO}\right)_{2}\left(0.5 \mathrm{~mol} \mathrm{~L}^{-1}\right)$ until the $\mathrm{pH}$ of the solution was 8 . The resulting suspension was stirred at room temperature for $12 \mathrm{~h}$. The precipitate was collected by filtration, washed with distilled water, and dried at $373 \mathrm{~K}$ for $24 \mathrm{~h}$. The solid was calcined in air at $673 \mathrm{~K}$ for $4 \mathrm{~h}$.

Copper oxide $(\mathrm{CuO})$ was prepared by calcining $\mathrm{Cu}\left(\mathrm{NO}_{3}\right)_{2} \cdot 6 \mathrm{H}_{2} \mathrm{O}$ in air at $673 \mathrm{~K}$ for $4 \mathrm{~h}$. Magnesium oxide $(\mathrm{MgO})$ and aluminum oxide $\left(\mathrm{Al}_{2} \mathrm{O}_{3}\right)$ were supplied by Ube Materials Co. (Magnesia 500A) and Japan AEROSIL Co. $\left(\right.$ Aerosil $^{\circledR}$ Alu C), respectively, and were calcined in air at $773 \mathrm{~K}$ for $5 \mathrm{~h}$ before use.

\subsection{Characterization}

Powder X-ray diffraction (XRD) patterns were recorded on an X-Ray diffractometer (Rigaku, Miniflex) with $\mathrm{Cu} \mathrm{K \alpha}$ radiation $(\lambda=0.154 \mathrm{~nm}, 30 \mathrm{kV}, 15 \mathrm{~mA})$ at room temperature. Crystallite sizes were estimated by applying Scherrer's equation to the strongest diffraction line for each 
sample. Specific surface areas were estimated by applying the Brunauer-Emmett-Teller (BET) equation to an adsorption isotherm of $\mathrm{N}_{2}$ at $77 \mathrm{~K}$, which was acquired on a Belsorp-mini instrument (BEL Japan Inc.). The samples were dried under $\mathrm{N}_{2}$ for $3 \mathrm{~h}$ at $473 \mathrm{~K}$ before the measurements.

\subsection{Catalytic ozonation of $\mathrm{NH}_{4}{ }^{+}$in water}

Catalytic ozonation of $\mathrm{NH}_{4}{ }^{+}$in water was performed by using the batch reactor shown in Fig. 1 .

An aqueous solution of $\mathrm{NH}_{4} \mathrm{Cl}\left(100 \mathrm{~mL}, 10 \mathrm{mmol} \mathrm{L}^{-1}\right.$, and $\left.\mathrm{pH}=5.4\right)$ (Wako Pure Chem. Ind. Ltd.) was heated to $333 \mathrm{~K}$ with vigorous stirring in a stream of $\mathrm{O}_{2}\left(100 \mathrm{~cm}^{3} \mathrm{~min}^{-1}\right)$. At $333 \mathrm{~K}$, the catalyst powder $(0.1 \mathrm{~g})$ was added to the reaction solution, and the gas was changed to a mixture of $\mathrm{O}_{3} / \mathrm{O}_{2}\left(1.88 \mathrm{mmol} \mathrm{L}^{-1}\right.$ as $\mathrm{O}_{3}$, total flow rate $\left.=100 \mathrm{~cm}^{3} \mathrm{~min}^{-1}\right)$ to start the catalytic ozonation of $\mathrm{NH}_{4}^{+}$. $\mathrm{O}_{3}$ was generated from $\mathrm{O}_{2}$ using an ozone generator (Tokyu Car Co. SO-03UN-OX). A portion of the reaction solution was periodically withdrawn, and the concentrations of $\mathrm{NO}_{3}{ }^{-}, \mathrm{NO}_{2}^{-}$, and $\mathrm{NH}_{4}{ }^{+}$ in the solution were determined by using two ion chromatographs (Tosoh Co. Ltd., IC-2001). A column containing an anion-exchange resin (TSK gel Super IC-AZ, Tosoh) and an aqueous solution of $\mathrm{NaHCO}_{3}\left(2.9 \mathrm{mmol} \mathrm{L}^{-1}\right)$ and $\mathrm{Na}_{2} \mathrm{CO}_{3}\left(3.1 \mathrm{mmol} \mathrm{L}^{-1}\right)$ were used as stationary and mobile phases, respectively, for anion analysis. For cation analysis, a column containing an cation-exchange resin (TSK gel IC-Cation 1/2 HR, Tosoh) and an aqueous solution of methanesulfonic acid (2.2 mmol 
$\left.\mathrm{L}^{-1}\right)$ and 18-crown-6 (1.0 mmol $\left.\mathrm{L}^{-1}\right)$ were used as stationary and mobile phases, respectively.

Yield of and selectivity to $\mathrm{NO}_{3}^{-}$were calculated by eqs. 4 and 5, respectively.

$$
\begin{aligned}
& \text { Yield of } \mathrm{NO}_{3}^{-}=\frac{\text { Concentration of formed } \mathrm{NO}_{3}^{-}}{\text {Initial concentration of } \mathrm{NH}_{4}^{+}} \times 100[\%] \\
& \text { Selectivity to } \mathrm{NO}_{3}^{-}=\frac{\text { Concentration of formed } \mathrm{NO}_{3}^{-}}{\text {Concentration of consumed } \mathrm{NH}_{4}^{+}} \times 100[\%]
\end{aligned}
$$

The selectivity to gaseous products was calculated by subtracting the selectivity for $\mathrm{NO}_{3}{ }^{-}$, which was the only product in solution, from $100 \%$. For each experiment, the $\mathrm{pH}$ of the reaction solution was measured after the reaction. Dissolution degree $(\%)$ of the catalyst during the reaction was calculated by eq. 6 , where $W_{\text {dissolved }}$ and $W_{\text {initial }}$ indicate the amounts of the metal dissolved in the reaction solution after $6 \mathrm{~h}$ and of that initially contained in the catalyst, respectively. $W_{\text {dissolved }}$ was determined by using an ICP-AES instrument (Shimadzu Co., ICPS-7000), and $W_{\text {initial }}$ was calculated based on the chemical formula:

$$
\text { Dissolution degree }=\frac{W_{\text {dissolved }}}{W_{\text {initial }}} \times 100[\%]
$$


For some reactions, we collected the gas phase products at the outlet of the reactor with a gas collection bag and analyzed them by using a gas chromatograph (Shimadzu Co., GC-8A) equipped with a TCD detector and a Porapack ${ }^{\circledR} \mathrm{Q}$ column. In addition, the catalytic ozonation of $\mathrm{NH}_{4}{ }^{+}$in water over $\mathrm{Co}_{3} \mathrm{O}_{4}$ was carried out by using a reaction solution prepared from $\left(\mathrm{NH}_{4}\right)_{2} \mathrm{SO}_{4}$ in the presence as well as absence of $\mathrm{NaCl}$ to investigate the role of $\mathrm{Cl}^{-}$in the catalytic cycle of the ozonation of $\mathrm{NH}_{4}{ }^{+}$.

\section{Results and discussion}

\subsection{Physical properties of metal oxide catalysts}

Fig. 2 shows powder XRD patterns of the catalysts before the catalytic ozonation. All catalysts were crystalline and only exhibited the characteristic diffraction patterns for the metal oxides listed in Table 1. The powder XRD patterns of the catalysts after the reaction were essentially identical to those before the reaction, but $\mathrm{MgO}$ and $\mathrm{Mn}_{3} \mathrm{O}_{4}$ reacted to give $\mathrm{Mg}(\mathrm{OH})_{2}$ and $\mathrm{Mn}_{5} \mathrm{O}_{8}$ by oxidation, respectively, during the reaction.

Table 1 lists chemical formulae and crystallite sizes estimated from powder XRD patterns and specific surface areas for the catalysts. $\mathrm{SnO}_{2}$ and $\mathrm{Al}_{2} \mathrm{O}_{3}$ had large surface areas, whereas the surface areas of $\mathrm{ZnO}$ and $\mathrm{CuO}$ were very small due to large crystallite sizes. The other catalysts, 
including $\mathrm{MgO}, \mathrm{NiO}, \mathrm{Co}_{3} \mathrm{O}_{4}, \mathrm{Mn}_{3} \mathrm{O}_{4}$, and $\mathrm{Fe}_{2} \mathrm{O}_{3}$, had moderate surface areas in the range of 10-35

$\mathrm{m}^{2} \mathrm{~g}^{-1}$

\subsection{Catalytic performances of the metal oxide catalysts}

Fig. 3 shows the conversion of $\mathrm{NH}_{4}{ }^{+}$in the absence and presence of the catalysts at $6 \mathrm{~h} . \mathrm{NH}_{4}^{+}$ decomposed even when no catalyst was present, as reported previously [20], but the conversion was low (14\%). In contrast, high conversions were obtained in the presence of the metal oxide catalysts. Among the catalysts, $\mathrm{MgO}$ was the most active catalyst, and $\mathrm{NiO}$ was the second. On the other hand, $\mathrm{Fe}_{2} \mathrm{O}_{3}, \mathrm{SnO}_{2}$, and $\mathrm{Al}_{2} \mathrm{O}_{3}$ scarcely promoted the reaction, even though the latter two catalysts had large surface areas. $\mathrm{Co}_{3} \mathrm{O}_{4}$ exhibited moderate catalytic activity with a $74 \%$ conversion, whereas $\mathrm{CuO}, \mathrm{ZnO}$, and $\mathrm{Mn}_{3} \mathrm{O}_{4}$ showed lower catalytic activity. The decomposition of $\mathrm{NH}_{4}{ }^{+}$did not proceed at all when only $\mathrm{O}_{2}$ was fed into the reaction solution even in the presence of the catalysts.

A good catalyst must have a high selectivity to gaseous products, including $\mathrm{N}_{2}$ and $\mathrm{N}_{2} \mathrm{O}$, in the oxidative decomposition of $\mathrm{NH}_{4}{ }^{+}$in water because the formation of soluble compounds, including $\mathrm{NO}_{3}^{-}$and $\mathrm{NO}_{2}^{-}$, must be suppressed to low levels due to their high toxicities. Fig. 4 shows the selectivities to gaseous compounds and $\mathrm{NO}_{3}{ }^{-}$in the ozonation of $\mathrm{NH}_{4}{ }^{+}$in the absence and presence 
of the metal oxide catalysts at $6 \mathrm{~h} . \quad \mathrm{NO}_{2}^{-}$did not form at all regardless of the catalyst. $\mathrm{MgO}$ and $\mathrm{NiO}$ showed low selectivity to gaseous products, although they had high catalytic activities, as shown in Fig. 3. In fact, when they were used, a large amount of harmful $\mathrm{NO}_{3}{ }^{-}$formed, making them unsuitable for use as catalysts in the purification of wastewater containing ammonia nitrogen. $\mathrm{CuO}$ and $\mathrm{ZnO}$ were less selective to gaseous products. In contrast, it should be noted that $\mathrm{Co}_{3} \mathrm{O}_{4}$ exhibited the highest selectivity to gaseous products (88\%). For the reaction over $\mathrm{Co}_{3} \mathrm{O}_{4}$, only $\mathrm{N}_{2}$ was detected as a gaseous product by using GC analysis. From the conversion (74\%) and selectivity to $\mathrm{NO}_{3}{ }^{-}(12 \%)$ at $6 \mathrm{~h}$ for $\mathrm{Co}_{3} \mathrm{O}_{4}$, the yield of $\mathrm{NO}_{3}{ }^{-}$was calculated to be $9 \%$. When the reaction was conducted in the absence of the catalyst, the yield of $\mathrm{NO}_{3}{ }^{-}$was $9 \%$. In other words, almost all of the $\mathrm{NO}_{3}{ }^{-}$formed in the presence of $\mathrm{Co}_{3} \mathrm{O}_{4}$ was produced by homogeneous oxidation of $\mathrm{NH}_{4}{ }^{+}$with $\mathrm{O}_{3}$ in water.

In addition to the activity and selectivity, the catalysts must be insoluble to be a good catalyst for practical use. Table 2 summarizes dissolution degrees for the catalysts and the $\mathrm{pH}$ values of the reaction solutions after $6 \mathrm{~h} . \mathrm{MgO}, \mathrm{NiO}, \mathrm{CuO}$, and $\mathrm{ZnO}$ had the highest dissolution degrees in the reaction solutions. In contrast, $\mathrm{Mn}_{3} \mathrm{O}_{4}, \mathrm{Fe}_{2} \mathrm{O}_{3}$, and $\mathrm{SnO}_{2}$ were insoluble in the reaction solution, despite being less active and/or less selective to gaseous products. Only $1 \%$ of $\mathrm{Co}_{3} \mathrm{O}_{4}$ dissolved in the reaction solution during the reaction. As eqs. 1-3 indicate, protons were formed by the 
ozonation of $\mathrm{NH}_{4}{ }^{+}$in water, resulting in a decrease in the $\mathrm{pH}$ of the reaction solution as the reaction progressesed. In fact, the $\mathrm{pH}$ of the reaction solution after the reaction was less than 2.5 for the insoluble $\left(\mathrm{Mn}_{3} \mathrm{O}_{4}, \mathrm{Fe}_{2} \mathrm{O}_{3}\right.$, and $\left.\mathrm{SnO}_{2}\right)$ and less soluble catalysts $\left(\mathrm{Co}_{3} \mathrm{O}_{4}\right.$ and $\left.\mathrm{Al}_{2} \mathrm{O}_{3}\right)$, although the initial $\mathrm{pH}$ of the reaction solution was 5.4. On the other hand, when $\mathrm{MgO}, \mathrm{NiO}, \mathrm{ZnO}$, and $\mathrm{CuO}$ were used, the $\mathrm{pH}$ of the reaction solution after the reaction was relatively high because they had a higher degree of dissolution during the reaction. From these results, we concluded that $\mathrm{Co}_{3} \mathrm{O}_{4}$ was the best catalyst in terms of activity, selectivity to gaseous compounds, and dissolution degree among the catalysts that we tested. In addition, $\mathrm{Co}_{3} \mathrm{O}_{4}$ was reusable for the reaction. After the reaction, $\mathrm{Co}_{3} \mathrm{O}_{4}$ was separated by filtration, dried at $383 \mathrm{~K}$ overnight and then was afforded to the second reaction. The conversion of the second reaction was $91 \%$ with similar selectivity to the first one. It should be noted that the conversion of the second reaction was much higher than that of the first one (74\%). For the third reaction, the activity was further increased and $\mathrm{NH}_{4}{ }^{+}$was completely decomposed at $6 \mathrm{~h}$. Reconstitution of the surface of $\mathrm{Co}_{3} \mathrm{O}_{4}$ might occur during the reaction and may be one of the reasons for such improvement in the activity, but further investigation is necessary.

The surface area of the catalyst is one of the factors controlling the catalytic activity because the reaction takes place on the surface, and therefore, a catalyst with high surface area may show 
high activity. In Fig. 5, the conversions of $\mathrm{NH}_{4}{ }^{+}$, which were obtained by subtracting the conversion without catalyst from corresponding conversions in the presence of the catalyst, are plotted as a function of the surface areas of the catalysts. In Fig. 5, the data for $\mathrm{MgO}, \mathrm{NiO}, \mathrm{ZnO}$, and $\mathrm{CuO}$ were not plotted because they are soluble. As Fig. 5 clearly shows, $\mathrm{Co}_{3} \mathrm{O}_{4}$ (Fig. 5(a)) had the highest activity despite its small surface area.

Next we discuss the catalyst properties that control the selectivity. Fig. 6 shows a plot of the selectivities to gaseous products as a function of standard enthalpy change of formation per mol of oxygen atom $\left(\Delta H_{\mathrm{f}}^{\circ}\right)$ of the metal oxides. The selectivity to gaseous products was low for the catalysts with a large value of $\Delta H_{\mathrm{f}}^{\circ}$, like $\mathrm{MgO}$ and $\mathrm{ZnO}$, and increased as $\Delta H_{\mathrm{f}}^{\circ}$ decreased. The catalysts showing moderate to high selectivity to gaseous products had a value of $\Delta H_{\mathrm{f}} \leq 60 \mathrm{kcal}$ $(\mathrm{mol} \text { of } \mathrm{O})^{-1}$.

In the catalytic oxidation of $\mathrm{NH}_{4}{ }^{+}$, two nitrogen intermediate species ( $\mathrm{NH} x$ ) must react to form gaseous products (bimolecular reaction). On the other hand, $\mathrm{NO}_{3}^{-}$is formed when one nitrogen species reacts with active oxygen $\left(\mathrm{O}^{*}\right)$ (monomolecular reaction), which forms when $\mathrm{O}_{3}$ reacts with the catalyst surface. Thus, the ratio of the surface densities of the nitrogen intermediate species and active oxygen atoms $\left([\mathrm{NH} x] /\left[\mathrm{O}^{*}\right]\right)$ would determine the selectivity. If $[\mathrm{NH} x] /\left[\mathrm{O}^{*}\right]$ is high, namely, $[\mathrm{NH} x]$ is high or $\left[\mathrm{O}^{*}\right]$ is low, the selectivity to gaseous products becomes high. It is 
reasonable that $\Delta H_{\mathrm{f}}$ indicates the bond strength between the metal cation $(\mathrm{M})$ and lattice oxygen (M-O) in the metal oxides. Thus, the metal oxides with small $\Delta H_{\mathrm{f}}^{\circ}$ values have weak M-O bond strengths. If this relationship can be extended to the bond strengths between $\mathrm{M}$ on the surface and $\mathrm{O}^{*}$ formed by the reaction of $\mathrm{O}_{3}$ with the surface, $\mathrm{O}^{*}$ formed on the catalysts with small $\Delta H_{\mathrm{f}}^{\circ}$ values would be unstable, meaning it is highly active. In other words, $\mathrm{O}^{*}$ will be consumed and removed from the surface rapidly due to its high reactivity. As a result, the surface density of the $\mathrm{O}^{*}$ is low for the catalysts with small $\Delta H_{\mathrm{f}}^{\circ}$ values, leading to the high selectivity to gaseous products. We think that this is one of the reasons for the high selectivity to gaseous products over catalysts like $\mathrm{Co}_{3} \mathrm{O}_{4}$. If the hypothesis that the $[\mathrm{NH} x] /\left[\mathrm{O}^{*}\right]$ ratio on the surface determines the selectivity is true, the concentration of $\mathrm{NH}_{4}{ }^{+}$in water must affect the selectivity. To demonstrate this, we carried out the catalytic ozonation of $\mathrm{NH}_{4}{ }^{+}$over $\mathrm{Co}_{3} \mathrm{O}_{4}$ using an aqueous solution of $\mathrm{NH}_{4} \mathrm{Cl}$ with $5 \mathrm{mmol} \mathrm{L}$. The result showed that the selectivity to gaseous products at $6 \mathrm{~h}$ was $66 \%$, which was lower than that with $10 \mathrm{mmol} \mathrm{L}^{-1}$ solution (88\%). This result supports the reaction mechanism we proposed.

\subsection{Participation of $\mathrm{Cl}^{-}$in the catalytic cycle over $\mathrm{Co}_{3} \mathrm{O}_{4}$}

Fig. 7 shows time courses of the conversion and selectivity to gaseous products for the ozonation of $\mathrm{NH}_{4}{ }^{+}$over $\mathrm{Co}_{3} \mathrm{O}_{4}$. The selectivity was independent of the reaction time. It is noted 
that an induction period was observed for the conversion of $\mathrm{NH}_{4}{ }^{+}$. There are two explanations for the appearance of the induction period. One is that the formation rate of $\mathrm{O}^{*}$ on the surface of $\mathrm{Co}_{3} \mathrm{O}_{4}$ is slow. However, the induction period was also observed for the reaction over $\mathrm{Co}_{3} \mathrm{O}_{4}$ pretreated with $\mathrm{O}_{3}$ for $3 \mathrm{~h}$ at $333 \mathrm{~K}$ in the absence of $\mathrm{NH}_{4}{ }^{+}$in water. In addition, the conversion and selectivity were identical to the reaction without $\mathrm{O}_{3}$ pretreatment. The second explanation is that $\mathrm{Cl}^{-}$participates in the ozonation of $\mathrm{NH}_{4}{ }^{+}$; namely, $\mathrm{Cl}^{-}$is first oxidized by $\mathrm{O}_{3}$ over $\mathrm{Co}_{3} \mathrm{O}_{4}$ to form $\mathrm{ClO}^{-}$, which oxidizes $\mathrm{NH}_{4}{ }^{+}$. In the reaction solution, $\mathrm{Cl}^{-}$and $\mathrm{NH}_{4}{ }^{+}$were both present in the same amount because $\mathrm{NH}_{4} \mathrm{Cl}$ was used as the source of $\mathrm{NH}_{4}{ }^{+}$. To determine if $\mathrm{Cl}^{-}$participates in the catalytic cycle for the ozonation of $\mathrm{NH}_{4}{ }^{+}$, we carried out the catalytic ozonation of $\mathrm{NH}_{4}{ }^{+}$over $\mathrm{Co}_{3} \mathrm{O}_{4}$ using $\left(\mathrm{NH}_{4}\right)_{2} \mathrm{SO}_{4}$ as the source of $\mathrm{NH}_{4}^{+}$, i.e., without $\mathrm{Cl}^{-}$. Even after $6 \mathrm{~h}$, the $\mathrm{NH}_{4}^{+}$ conversion was zero, suggesting that $\mathrm{Cl}^{-}$in water participates in the catalytic cycle for the ozonation of $\mathrm{NH}_{4}{ }^{+}$over $\mathrm{Co}_{3} \mathrm{O}_{4}$.

To further confirm the participation of $\mathrm{Cl}^{-}$, we examined the concentration dependence of $\mathrm{Cl}^{-}$ in the reaction solution on the catalytic ozonation of $\mathrm{NH}_{4}^{+}$over $\mathrm{Co}_{3} \mathrm{O}_{4}$. The reaction was conducted in a reaction solution prepared using $\left(\mathrm{NH}_{4}\right)_{2} \mathrm{SO}_{4}$ and different concentrations of $\mathrm{Cl}^{-}$, where the concentration of $\mathrm{Cl}^{-}$was controlled by adding $\mathrm{NaCl}$ to the solution. With an increase in the concentration of $\mathrm{Cl}^{-}$, the conversion of $\mathrm{NH}_{4}{ }^{+}$increased, and the selectivity to gaseous products 
was similar to that for the reaction in the $\mathrm{NH}_{4} \mathrm{Cl}$ solution. This result clearly demonstrates that $\mathrm{Cl}^{-}$ is involved in the catalytic cycle for the ozonation of $\mathrm{NH}_{4}{ }^{+}$over $\mathrm{Co}_{3} \mathrm{O}_{4}$. Haag et al. have proposed a reaction scheme for the ozonation of $\mathrm{NH}_{4}{ }^{+}$in water in the presence of $\mathrm{Br}^{-}$without any heterogeneous catalyst under neutral to mild alkaline conditions [24]. In the proposed mechanism, $\mathrm{Br}^{-}$is oxidized with $\mathrm{O}_{3}$ to form $\mathrm{BrOH}$, which then reacts with $\mathrm{NH}_{3}$ to form $\mathrm{NH}_{2} \mathrm{Br}$. Finally, $\mathrm{NH}_{2} \mathrm{Br}$ reacts with $\mathrm{O}_{3}$ to form $\mathrm{NO}_{3}{ }^{-}$, and at the same time, $\mathrm{Br}^{-}$is regenerated in the solution. They have demonstrated that the first step (HOBr formation) is the rate-determining step. In the present study, the oxidation of $\mathrm{Cl}^{-}$with $\mathrm{O}_{3}$ may take place over $\mathrm{Co}_{3} \mathrm{O}_{4}$ to form $\mathrm{ClO}^{-}$, meaning that this reaction is the rate-determining step in the catalytic ozonation of $\mathrm{NH}_{4}{ }^{+}$in the presence of $\mathrm{Co}_{3} \mathrm{O}_{4}$. Actually, $\mathrm{NO}_{3}^{-}$was produced by a homogeneous reaction, as discussed in Section 3.2. However, gaseous products $\left(\mathrm{N}_{2}\right.$ and $\left.\mathrm{N}_{2} \mathrm{O}\right)$ selectively formed over $\mathrm{Co}_{3} \mathrm{O}_{4}$ (Fig. 4). Thus, $\mathrm{Co}_{3} \mathrm{O}_{4}$ not only promotes the oxidation of $\mathrm{Cl}^{-}$with $\mathrm{O}_{3}$ but also the formation of gaseous $\mathrm{N}_{2}$ and $\mathrm{N}_{2} \mathrm{O}$. On $\mathrm{Co}_{3} \mathrm{O}_{4}$, nitrogen-containing intermediates are preferentially activated to form the gaseous $\mathrm{N}_{2}$ and $\mathrm{N}_{2} \mathrm{O}$ through bimolecular reactions. Further investigations on the reaction mechanism, including kinetic analysis and determination of the surface densities of nitrogen-containing intermediates and active oxygen, are needed. 


\section{Conclusions}

Catalytic oxidation of $\mathrm{NH}_{4}{ }^{+}$with $\mathrm{O}_{3}$ in water over a variety of metal oxide catalysts, including $\mathrm{Co}_{3} \mathrm{O}_{4}, \mathrm{NiO}, \mathrm{ZnO}, \mathrm{Fe}_{2} \mathrm{O}_{3}, \mathrm{SnO}_{2}, \mathrm{Mn}_{3} \mathrm{O}_{4}, \mathrm{CuO}, \mathrm{MgO}$, and $\mathrm{Al}_{2} \mathrm{O}_{3}$, without $\mathrm{pH}$ control was studied. $\mathrm{MgO}$ and $\mathrm{NiO}$ had the highest activity, but large amounts of undesired $\mathrm{NO}_{3}{ }^{-}$formed due to their low selectivity to gaseous products as well as high activity. Although $\mathrm{Co}_{3} \mathrm{O}_{4}$ was slightly less active than $\mathrm{MgO}$ and $\mathrm{NiO}$, it was the best catalyst in terms of activity, selectivity to gaseous products, and dissolution degree among the metal oxide catalysts. An aqueous solution of $\mathrm{NH}_{4}{ }^{+}\left(10 \mathrm{mmol} \mathrm{L}^{-1}\right)$ was effectively oxidized to $\mathrm{N}_{2}$ with $88 \%$ selectivity at $333 \mathrm{~K}$ over $\mathrm{Co}_{3} \mathrm{O}_{4}$. The selectivities to gaseous products were strongly related to the standard enthalpy changes of formation per mol of oxygen atom $\left(\Delta H_{\mathrm{f}}^{\circ}\right)$ of the metal oxides, and the catalysts with low $\Delta H_{\mathrm{f}}^{\circ}$ values, like $\mathrm{Co}_{3} \mathrm{O}_{4}$, showed high selectivity to gaseous products probably due to a low surface density of the active oxygen formed upon the reaction of $\mathrm{O}_{3}$ with the catalyst surface. Chloride ions $\left(\mathrm{Cl}^{-}\right)$present in the reaction solution significantly accelerated the reaction rate of $\mathrm{NH}_{4}{ }^{+}$decomposition with $\mathrm{O}_{3}$ over $\mathrm{Co}_{3} \mathrm{O}_{4}$ because $\mathrm{Cl}^{-}$is directly involved in the catalytic cycle, in which $\mathrm{Cl}^{-}$reacts with $\mathrm{O}_{3}$ to form $\mathrm{ClO}^{-}$. 


\section{References}

[1] S. Imamura, D. Akira, S. Ishida, Ind. Eng. Chem. Prod. Res. Dev. 24 (1985) 75-80.

[2] G. Deiber, J.N. Foussard, H. Debellefontaine, Environ. Pollution 96 (1997) 311-319.

[3] R. Ukropec, B.F.M. Kuster, J.C. Schouten, R.A. van Santen, Appl. Catal. B. 23 (1999) 45-57.

[4] J. Taguchi, T. Okuhara, Appl. Catal. A. 194-195 (2000) 89-97.

[5] J. Taguchi, Y. Yoshinaga, T. Okuhara, Chem. Lett. (2001) 112.

[f] C.M. Hung, J.C. Lou, C.H. Lin, J. Environ. Eng. 130 (2004) 193-200.

[7] C.M. Hung, J. Hazard. Mater. 166 (2009) 1314-1320.

[8] L. Oliviero, J. Barbier Jr., D. Duprez, Appl. Catal. B 40 (2003) 163-184.

[9] A. Martin, F. Luck, U. Armbruster, L. Patria, J. Radnik, M Schneider, Top. Catal. 33 (2005) $155-169$.

[10] T.-L. Huang, K.R. Clifle, J.M. Macinnes, Environ. Sci. Technol. 34 (2000) 4804-4809.

[11] J. Barbier Jr., L. Oliviero, B. Renard, D. Duprez, Catal. Today 75 (2002) 29-34.

[12] B. Kasprzyk-Hordern, M. Ziòlek, J. Nawrocki, Appl. Catal. B 46 (2003) 639-669.

[13] J. Nawrocki, B. Kasprzyk-Hordern, Appl. Catal. B 99 (2010) 27-42.

[14] H. Einaga, S. Futamura, Appl. Catal. B 60 (2005) 49-55. 
[15] Y. Yang, J. Ma, Q. Qin, Z Zhai, J. Mol. Catal. A 267 (2007) 41-48.

[16] H. Einaga, A. Ogata, J. Hazard. Mater. 164 (2009) 1236-1241.

[17] H. Einaga, A. Ogata, Environ. Sci. Technol. 44 (2010) 2612-2617.

[18] P.C.C Faria, J.J.M. Orfao, M.F.R. Pereira, App. Catal. B 79 (2008) 237-243.

[19] P.M. Alvarez, F.J. Beltran, J.P. Pocostales, F.J. Masa, Appl. Catal. B 72 (2007) 322-330.

[20] M. Ernst, F. Lurot, J.-C. Schrotter, Appl. Catal. B 47 (2004) 15-25.

[21] J. Rivera-Utrilla, M. Sanchez-Polo, Appl, Catal. B 39 (2002) 319-329.

[22] F.J. Beltran, F.J. Rivas, R. Montero-de-Espinasa, Appl. Catal. B 39 (2002) 221-231.

[23] P.C. Singer, W.B. Zilli, Water. Res. 9 (1975) 127-134.

[24] W. R. Haag, J. Hoigne, H. Bader, Water Res. 18 (1984) 1125-1128. 
Table 1

Physical properties of the metal oxide catalysts used

\begin{tabular}{|c|c|c|c|}
\hline Catalyst & Chemical formula $^{a}$ & Crystallite size $^{\mathrm{b}} / \mathrm{nm}$ & Surface area ${ }^{\mathrm{c}} / \mathrm{m}^{2} \mathrm{~g}^{-1}$ \\
\hline Cobalt oxide & $\mathrm{Co}_{3} \mathrm{O}_{4}$ & 28 & 14 \\
\hline Nickel oxide & $\mathrm{NiO}$ & 25 & 22 \\
\hline Zinc oxide & $\mathrm{ZnO}$ & 45 & 1 \\
\hline Iron oxide & $\mathrm{Fe}_{2} \mathrm{O}_{3}$ & 32 & 10 \\
\hline Tin oxide & $\mathrm{SnO}_{2}$ & 8 & 82 \\
\hline Manganese oxide & $\mathrm{Mn}_{3} \mathrm{O}_{4}$ & 19 & 23 \\
\hline Copper oxide & $\mathrm{CuO}$ & 27 & 1 \\
\hline Magnesium oxide & $\mathrm{MgO}$ & 30 & 35 \\
\hline Aluminum oxide & $\mathrm{Al}_{2} \mathrm{O}_{3}$ & 8 & 93 \\
\hline
\end{tabular}

adetermined from powder XRD pattern.

bdetermined by applying Scherrer's equation to the strongest diffraction line in each XRD pattern.

cdetermined from $\mathrm{N}_{2}$ adsorption isotherm at $77 \mathrm{~K}$ by using the BET equation. 
Table 2

Dissolution degrees of the metal oxide catalysts used and the $\mathrm{pH}$ of the reaction solution after the reaction

\begin{tabular}{lcc}
\hline Catalyst & Dissolution degree $^{\mathrm{a}} \%$ & $\mathrm{pH}^{\text {after the reaction }}{ }^{\mathrm{b}}$ \\
\hline $\mathrm{MgO}$ & 38 & 9.3 \\
$\mathrm{NiO}$ & 56 & 6.3 \\
$\mathrm{Co}_{3} \mathrm{O}_{4}$ & 1 & 2.1 \\
$\mathrm{CuO}$ & 27 & 4.6 \\
$\mathrm{ZnO}$ & 26 & 6.2 \\
$\mathrm{Mn}_{3} \mathrm{O}_{4}$ & 0.1 & 2.1 \\
$\mathrm{Fe}_{2} \mathrm{O}_{3}$ & below detection limit & 2.6 \\
$\mathrm{SnO}_{2}$ & below detection limit & 2.7 \\
$\mathrm{Al}_{2} \mathrm{O}_{3}$ & 2 & 3.1 \\
\hline
\end{tabular}

${ }^{\mathrm{a}}$ Amount of metal dissolved in the reaction solution was determined by using ICP-AES.

${ }^{\mathrm{b}}$ Initial $\mathrm{pH}$ of the reaction solution was 5.4. 


\section{Figure captions}

Fig. 1 Schematic illustration of the reaction apparatus used for catalytic ozonation of $\mathrm{NH}_{4}{ }^{+}$in water.

Fig. 2 Powder XRD patterns of the metal oxide catalysts before catalytic ozonation of $\mathrm{NH}_{4}{ }^{+}$in water.

Fig. 3 Catalytic activities of the metal oxide catalysts used for ozonation of $\mathrm{NH}_{4}{ }^{+}$in water.

Reaction conditions: catalyst weight, $0.1 \mathrm{~g}$; $\left[\mathrm{NH}_{4}^{+}\right], 10 \mathrm{mmol} \mathrm{L} \mathrm{L}^{-1}$ from $\mathrm{NH}_{4} \mathrm{Cl}$; reaction solution volume, $100 \mathrm{~mL}$; reaction gas, $\mathrm{O}_{3} / \mathrm{O}_{2}$ mixture; total flow rate, $100 \mathrm{~cm}^{3} \mathrm{~min}^{-1} ; \mathrm{O}_{3}$ concentration, 0.7 vol\%; reaction temperature, $333 \mathrm{~K}$; and reaction time, $6 \mathrm{~h}$.

Fig. 4 Selectivities toward (口) $\mathrm{NO}_{3}^{-}$and (-) gaseous products in catalytic ozonation of $\mathrm{NH}_{4}{ }^{+}$in water over various metal oxide catalysts. Reaction conditions: catalyst weight, $0.1 \mathrm{~g}$; reaction solution, $\left[\mathrm{NH}_{4}^{+}\right], 10 \mathrm{mmol} \mathrm{L}$ from $\mathrm{NH}_{4} \mathrm{Cl}$; reaction solution volume, $100 \mathrm{~mL}$; reaction gas, $\mathrm{O}_{3} / \mathrm{O}_{2}$ mixture; total flow rate, $100 \mathrm{~cm}^{3} \mathrm{~min}^{-1} ; \mathrm{O}_{3}$ concentration, 0.7 vol\%; reaction temperature, $333 \mathrm{~K}$; and reaction time, $6 \mathrm{~h}$. 
Fig. 5 Relationship between conversion of $\mathrm{NH}_{4}{ }^{+}$at $6 \mathrm{~h}$ and surface areas of the metal oxide catalysts.

The conversions of $\mathrm{NH}_{4}{ }^{+}$shown in the figure were obtained by subtracting the blank (without catalyst) from corresponding conversion. The data plotted in the figure are for the catalysts with low degrees of dissolution. (a) $\mathrm{Co}_{3} \mathrm{O}_{4}$, (b) $\mathrm{Fe}_{2} \mathrm{O}_{3}$, (c) $\mathrm{Mn}_{3} \mathrm{O}_{4}$, (d) $\mathrm{SnO}_{2}$, and (e) $\mathrm{Al}_{2} \mathrm{O}_{3}$.

Fig. 6 Correlation between selectivity to gaseous products and the standard enthalpy change of formation per mol of one oxygen atom $\left(\Delta H_{\mathrm{f}}^{\circ}\right)$ of the metal oxide catalyst.

Fig. 7 Time courses of the conversion of $\mathrm{NH}_{4}{ }^{+}(\bullet)$ and selectivity to gaseous products ( $\square$ ) for the catalytic ozonation of $\mathrm{NH}_{4}{ }^{+}$in water over $\mathrm{Co}_{3} \mathrm{O}_{4}$. Reaction conditions: catalyst weight, $0.1 \mathrm{~g}$; reaction solution, $\left[\mathrm{NH}_{4}^{+}\right], 10 \mathrm{mmol} \mathrm{L}^{-1}$ from $\mathrm{NH}_{4} \mathrm{Cl}$; reaction solution volume, $100 \mathrm{~mL}$; reaction gas, $\mathrm{O}_{3} / \mathrm{O}_{2}$ mixture; total flow rate, $100 \mathrm{~cm}^{3} \mathrm{~min}^{-1} ; \mathrm{O}_{3}$ concentration, 0.7 vol\%; and reaction temperature, $333 \mathrm{~K}$. 


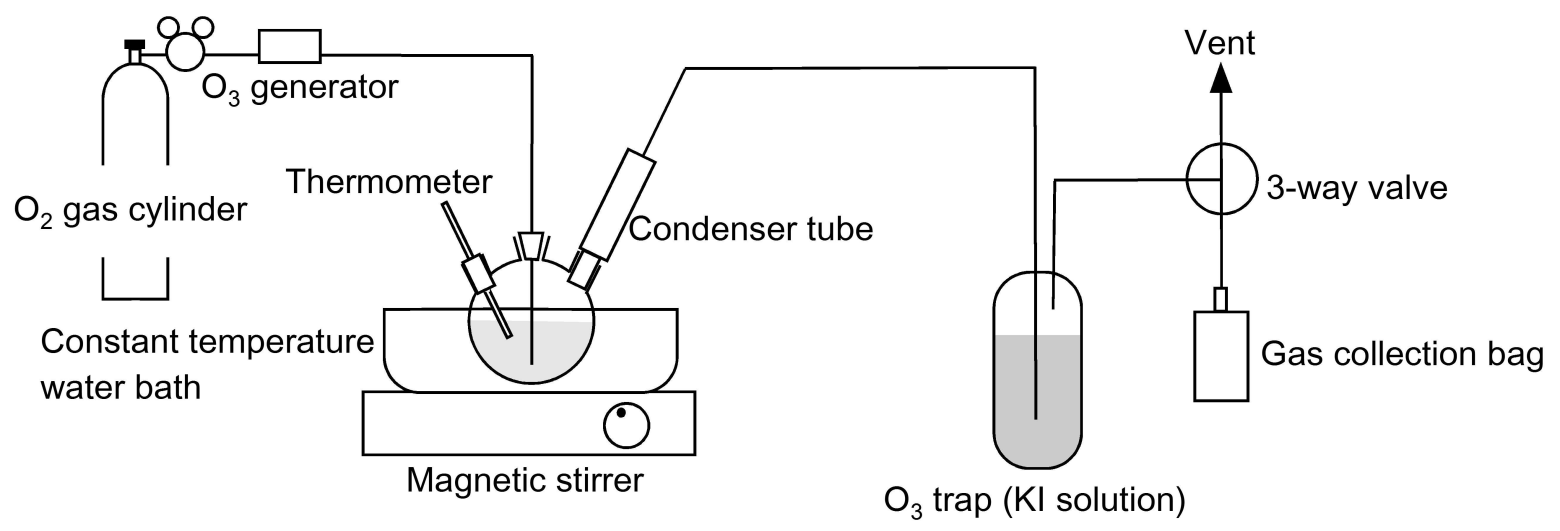

Fig. 1 


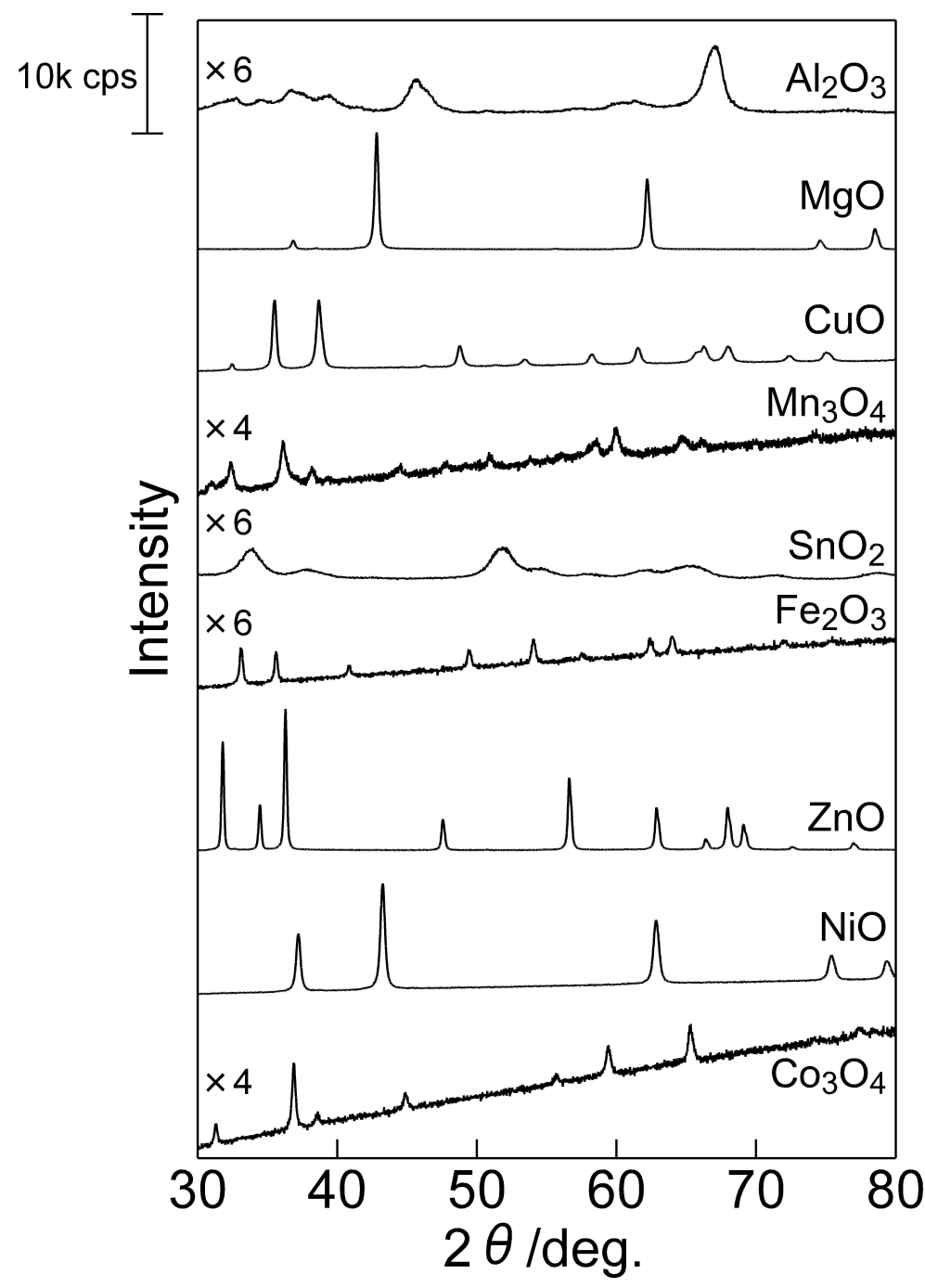

Fig. 2 


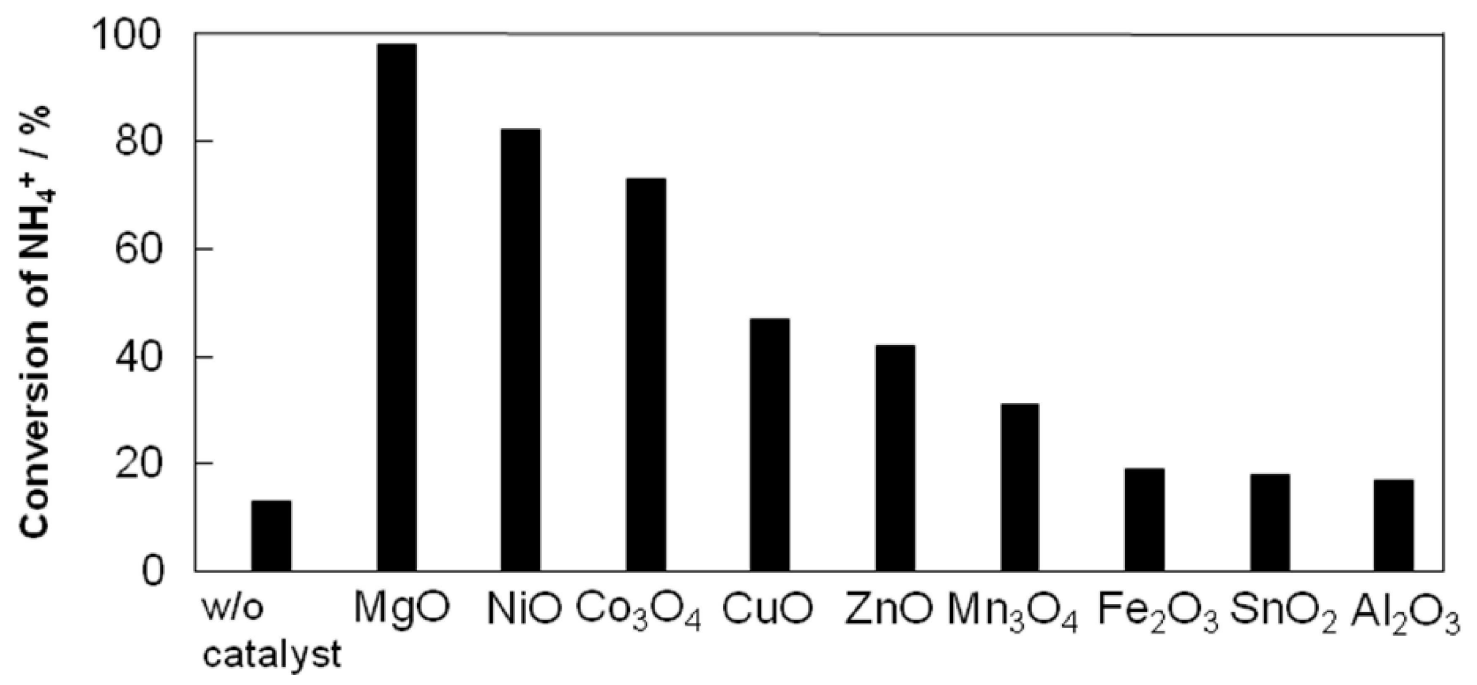

Fig. 3 


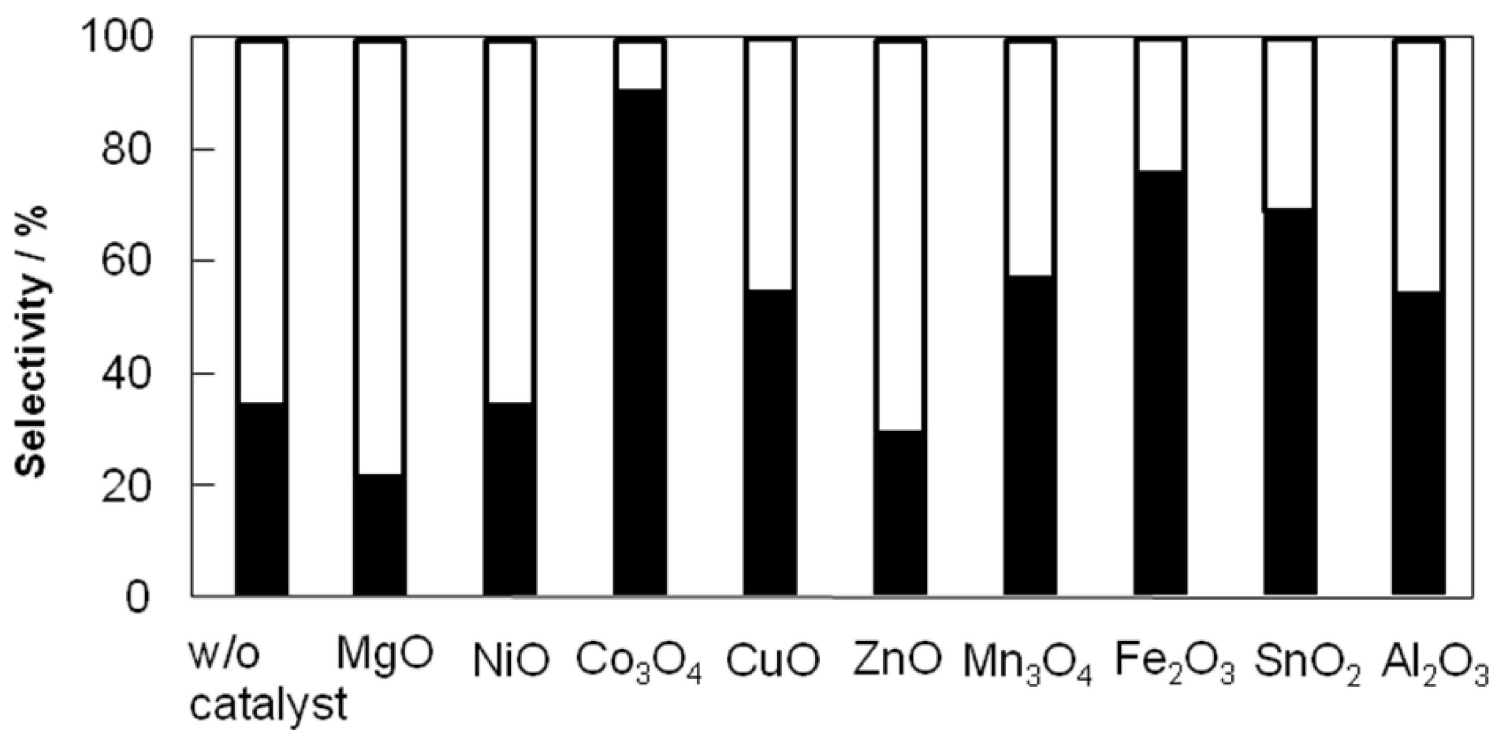

Fig. 4 


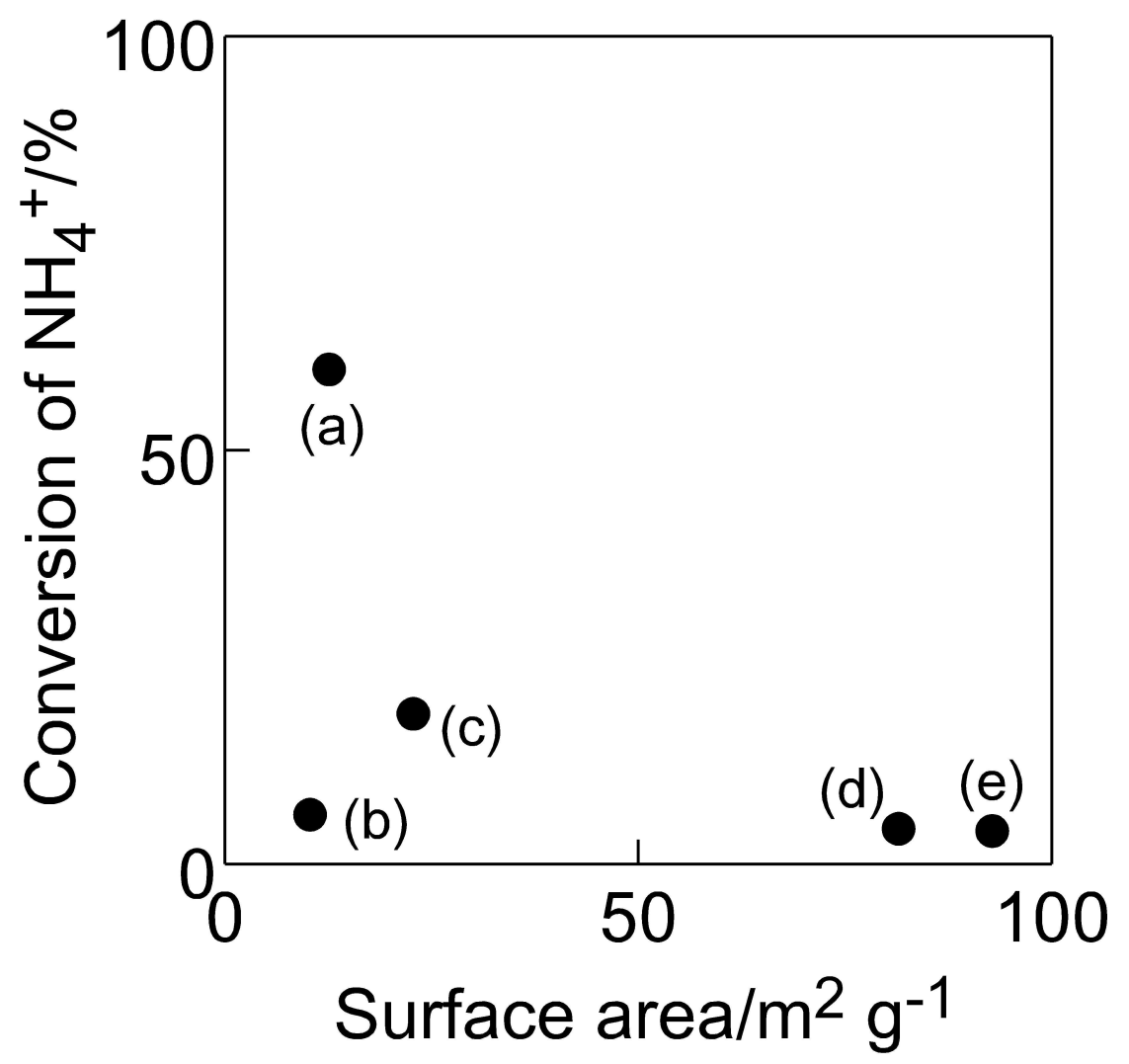

Fig. 5 


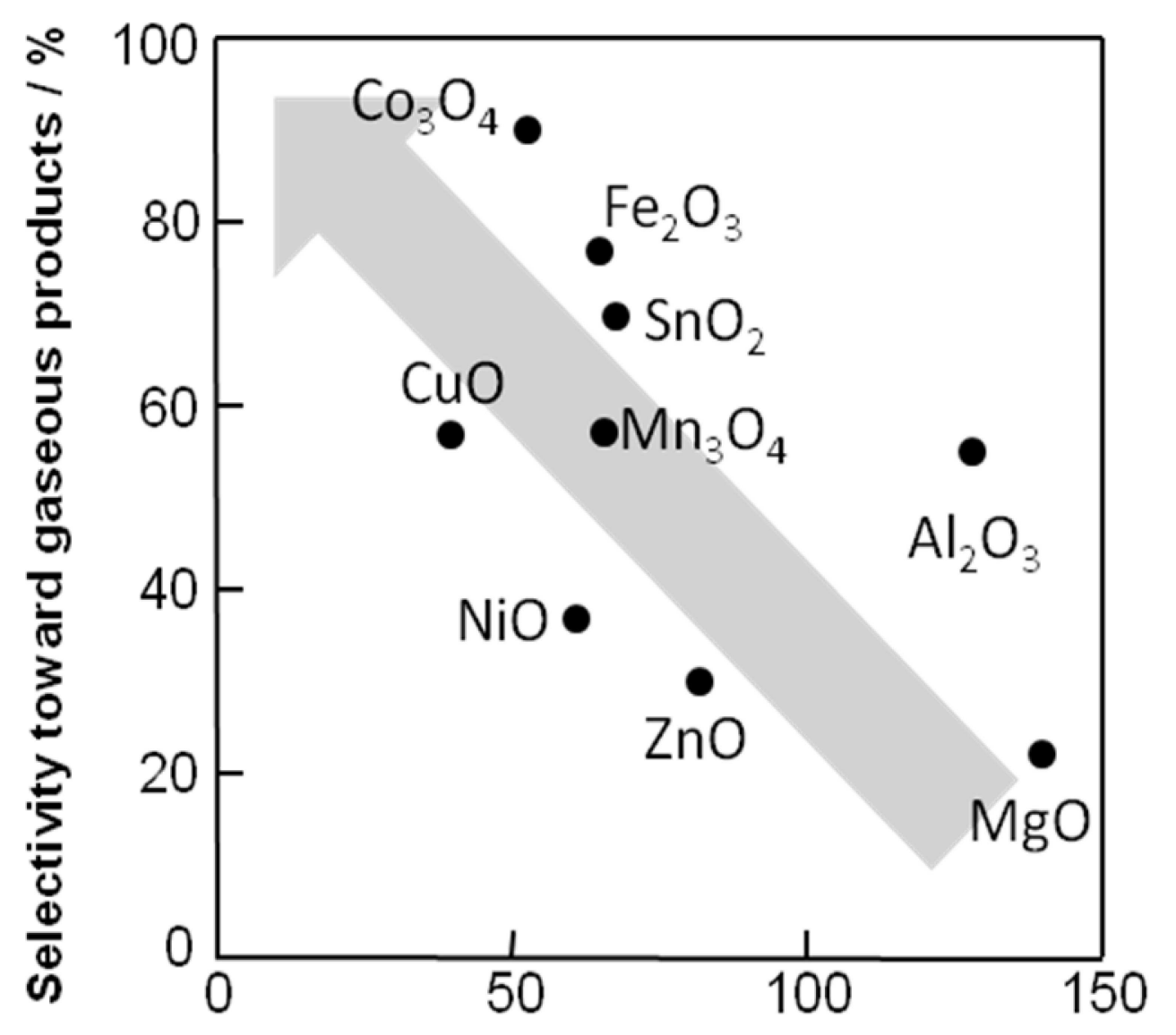

$\Delta \mathrm{Hf}$ of metal oxide $/ \mathrm{kcal}(\mathrm{mol} \text { of } \mathrm{O})^{-1}$

Fig. 6 


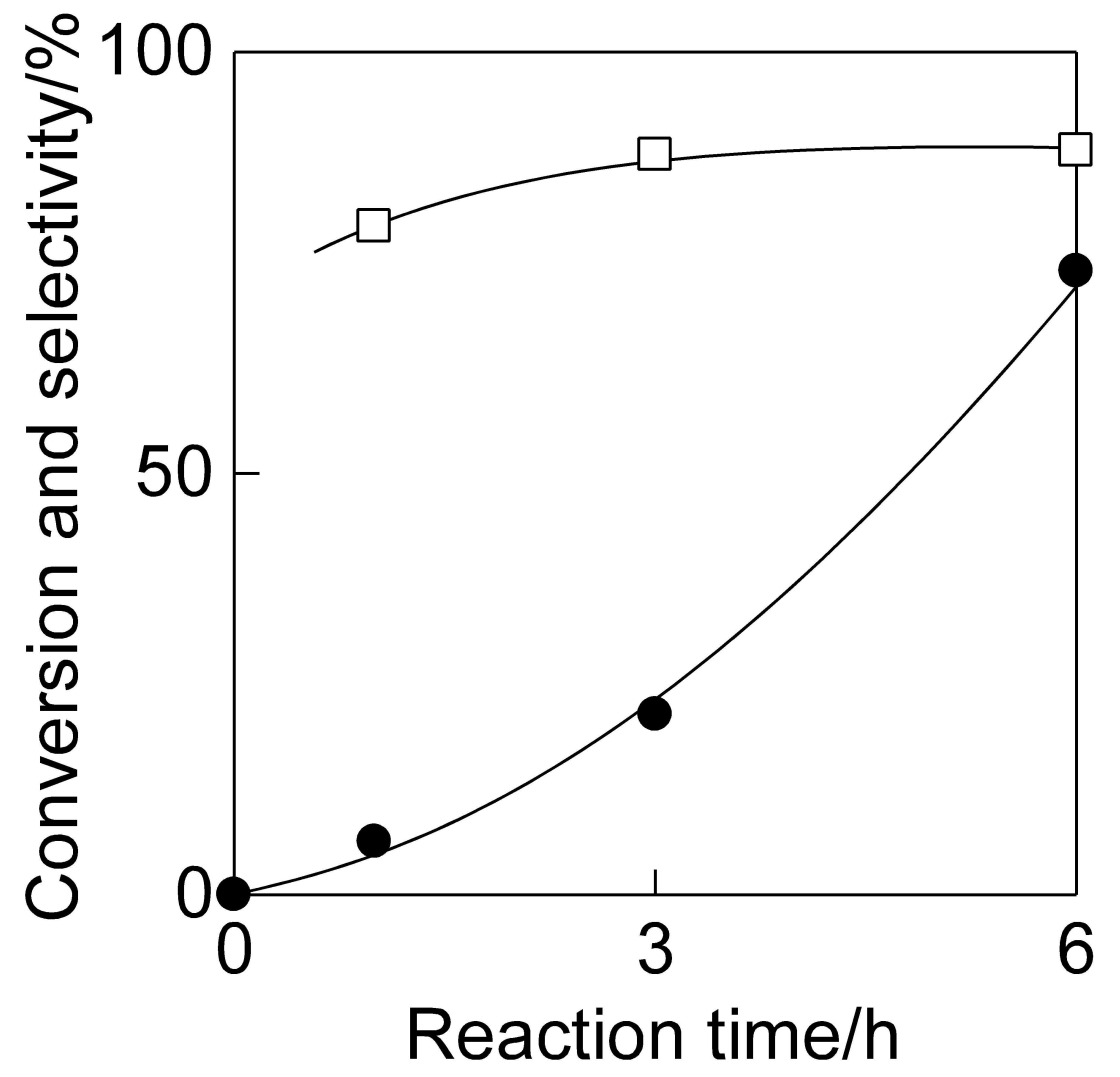

Fig. 7 